\title{
Językowy obraz dźwięku (na materiale polsko- i rosyjskojęzycznych recenzji muzycznych)
}

\section{The linguistic worldview of sound (based on Polish and Russian musical critical texts)}

\begin{abstract}
The aim of the article is to present the ways of conceptualization of sound in Polish and Russian musical critical texts. For the purpose of the article 145 examples in Polish and 145 examples in Russian were analyzed. The material has been divided into three groups based on the type of sense: a visual approach to sound impressions, a tactile approach to sound impressions and a tastebased approach to sound impressions. The analyzed research material was presented with the use of the linguistic worldview methodology, and grouped into categories. The results of the comparative analysis showed a multiplicity of similarities in the types of categories, as well as in the types of synaesthetic metaphors. The largest groups of conceptualizations are those with Aristotelian origin: QUALITY, SUBSTANCE and SHAPE. Synaesthetic metaphors based on the visual approach to sound impressions proved to be the most widespread. The analyzed texts have provided a huge variety of conceptualizations and synaesthetic metaphors in Polish and Russian musical critical texts which constitute a part of the linguistic worldview of sound.
\end{abstract}

Keywords: linguistic worldview, sound, synaesthesia, Russian, Polish

Maria Dzienisiewicz, Uniwersytet im. Adama Mickiewicza w Poznaniu, Poznań - Polska, maria.w.dzienisiewicz@gmail.com, ORCID ID: https://orcid.org/0000-0001-6140-6889

\section{Definicje dźwięku}

Mała encyklopedia muzyki określa dźwięk dwuaspektowo jako:

1. zaburzenie falowe w ośrodku sprężystym (inaczej: fala dźwiękowa), wywołujące wrażenie słuchowe;

2. samo wrażenie słuchowe (wrażenie dźwiękowe) (Śledziński 252).

Autorzy powyższej definicji odnotowują ponadto, że zasadniczo wyodrębniane są trzy obiektywne cechy dźwięku: częstotliwość, natężenie i widmo, przy czym należy uwzględniać ich zmiany w czasie trwania dźwięku. Odpowiadający- 
mi im subiektywnymi, wrażeniowymi cechami dźwięku są wysokość (zależna od częstotliwości), głośność (zależna od natężenia) oraz barwa (zależna od widma). Tym samym dźwięk może być ujmowany na dwóch płaszczyznach: w mierzalny, obiektywny sposób lub w sposób nieobiektywny, wrażeniowy, a więc odnoszący się do sfery psychologii ${ }^{1}$. Takie ujęcie dźwięku nie jest prezentowane w źródłach leksykograficznych.

W Stowniku języka polskiego pod redakcją Witolda Doroszewskiego interesujące nas zjawisko jest definiowane jako:

1. wrażenie słuchowe (będące reakcją na bodziec zewnętrzny);

2. fiz. drganie cząsteczek środowiska (powietrza, wody itp.) rozchodzące się w postaci fal i stanowiące bodziec wrażenia słuchowego;

3. jęz. dźwięk artykułowany wchodzący w skład wyrazów; głoska;

4. muz. brzmienie o określonej wysokości, natężeniu i barwie, złożone z tonów prostych wraz z ich tonami górnymi (alikwotami) (Doroszewski 628-629).

Autorzy słownika dodają, że „definicja dźwięków muzycznych jest wprawdzie sztuczna, ale prosta: są to dźwięki wydawane albo poprzez instrumenty muzyczne, albo przez głos ludzki" (Doroszewski 628-629). Mimo że ujęto takie właściwości, jak wysokość, natężenie i barwa, nie uwzględniono aspektu wrażeniowego (psychologicznego).

W Słowniku języka rosyjskiego pod redakcją Siergieja Iwanowicza Ożegowa pominięto nawet znaczenie dźwięku jako zjawiska muzycznego, definiując go następująco:

1. то, что слышится, воспринимается слухом: физическое явление, вызываемое колебательными движениями частиц воздуха или другой среды;

2. звуки речи, минимальные членораздельные элементы речи с присущими им физическими признаками (cneu.) (Ožegov 230).

Na muzyczne znaczenie zwraca jednak uwagę słownik Tatiany Jefremowej, w którym dźwięk został określony jako:

1. волнообразно распространяющееся колебательное движение материальных частиц упругой среды, воспринимаемое органами слуха; слуховое ощущение, вызываемое таким движением;

2. элементарная единица речи с присущими ей акустическими свойствами;

3. наименьший структурный элемент, обладающий определенной высотой, громкостью, длительностью, тембром (в музыке) (Efremova, źródło elektroniczne).

\footnotetext{
${ }^{1}$ Szerzej na temat definicji dźwięku zob. Żurowski 2009.
} 
Wspomniany we wstępie aspekt psychologiczny ma znaczenie zarówno w percepcji dźwięków, jak i w ich opisie, a więc werbalizacji. Należy podkreślić, że wszelkie próby opisu dźwięku, tego praelementu muzyki, muszą odwołać się do metafory. Eduard Hanslick, XIX-wieczny krytyk, twierdził, że „wszelkie fantazyjne przedstawienia, charakterystyki, opisy dzieła muzycznego są metaforyczne albo mylące. O ile w każdej innej sztuce coś jest opisem, w muzyce jest metaforą" (Hanslick 95). Szerokiego spektrum werbalizacji wrażeń dźwiękowych dostarczają recenzje muzyczne, będące subiektywnymi wypowiedziami słuchaczy, komentatorów wydarzeń. W niniejszym artykule zostaną zaprezentowane przykłady werbalizacji wrażeń dźwiękowych w języku polskim i rosyjskim zaczerpnięte z internetowych stron ruchmuzyczny.pl oraz musiccritics.ru. Wstępny ogląd materiału pozwolił skonstatować, że najliczniejszą i zarazem najbardziej zróżnicowaną pod względem językowym grupę werbalizacji stanowią jednostki wykorzystujące mechanizm synestezji ${ }^{2}$.

W Stowniku terminów literackich synestezja (z gr. syn 'razem' i aisthesis 'postrzeganie, odczuwanie') jest tłumaczona jako środek artystyczny, w ramach którego ,pewne doznania zmysłowe są przedstawiane w kategoriach właściwych innym zmysłom" (Sławiński 551). Innymi słowy, zjawisko synestezji występuje wtedy, gdy jednomodalny bodziec zmysłowy wywołuje mimowolnie jednoczesne wrażenie w dwu lub więcej modalnościach zmysłowych, np. słysząc dźwięk, osoba z synestezją widzi kolor (Rogowska 465). Najbardziej rozpowszechnionego typu synestezji, łączącej bodziec dźwiękowy ze wzrokowym, dotyczy wypowiedź Olivera Messiaena: „Toute impression, chez moi, se transforme en musique et toute musique correspond a une cheveau de couleurs determinees” („,Każde wrażenie [wzrokowe] przekształca się u mnie w muzykę i każda muzyka łączy się z pasmem określonych kolorów") (Messiaen, cyt. za: Kaczyński 16). Inny typ doznań synestezyjnych został zrelacjonowany przez Wasyla Kandyńskiego, który doświadczał współodczuwania elementów wzrokowych z dźwiękowymi, a nierzadko także taktylnymi (temperatura). Na temat płaszczyzny obrazu Kandyński wypowiedział się następująco: „Podstawowy ton płaszczyzny obrazu sam musi się narzucać: dwa zimne oraz dwa ciepłe elementy ciszy są dwoma dwudźwiękami ciszy i spokoju" (Kandyński 127). Podobnych synestezyjnych powiązań doszukiwał się w figurach geometrycznych: „Linia pozioma jest więc chłodną [z powodu pewnej pasywności], dźwigającą podstawą, która może być płasko przedłużona w obu kierunkach. Płaskie rozpościeranie się i chłód to podstawowy wyraz [dźwięk] tej linii” (Kandyński 57).

2 Szczegółowej analizy typów metafory synestezyjnej dokonali m.in. Sean A. Day (Day 1995, 1996) oraz Vilayanur S. Ramachandran i Edward M. Hubbard (Ramachandran, Hubbard). 
W prezentowanym w niniejszym artykule materiale synestezja przejawia się w ujmowaniu doznań słuchowych (dźwiękowych) w kategoriach właściwych zmysłom wzroku, dotyku oraz smaku. Kategorie te pozwolą zrekonstruować wycinek językowego obrazu dźwięku, stanowiący fragment tzw. językowego obrazu świata (JOS).

W 1978 roku Walery Pisarek podał definicję i charakterystykę JOS w Encyklopedii wiedzy o języku polskim (Urbańczyk). W 1980 roku opublikowano zeszyt próbny Stownika ludowych stereotypów językowych (Adamowski et al.). Ostatecznie językoznawcy jednak nie uzgodnili definicji JOS. Zdaniem Jerzego Bartmińskiego, który uczynił to pojęcie centralnym obiektem swoich zainteresowań badawczych, JOS

jest zawartą w języku, różnie zwerbalizowaną interpretacją rzeczywistości dającą się ująć w postaci zespołu sądów o świecie. Mogą to być sądy bądź to utrwalone w samym języku, w jego formach gramatycznych, słownictwie, kliszowanych tekstach (np. przysłów), bądź też przez formy i teksty języka implikowane (Bartmiński 12).

Koncepcję „modelu świata” i „naiwnego obrazu świata” rozwijano również na gruncie rosyjskim. Warte wzmiankowania są w tym kontekście prace przedstawicieli moskiewskiej szkoły semantycznej (Jurija D. Apresjana, Jurija M. Łotmana, Wiaczesława W. Iwanowa, Władimira N. Toporowa, Niny D. Arutiunowej, Nikity I. Tołstoja). Akcentują one, że u podstaw wspomnianych wcześniej pojęć leży częściowo uniwersalny, częściowo charakterystyczny dla danego języka schemat konceptualizacji (Apresjan). Próbę wstępnej syntezy problematyki językowego obrazu świata zawiera monografia wieloautorska Роль человеческого фактора в языке. Язык и картина мира z 1988 roku (Serebrennikov). Anna Zalizniak wyjaśnia termin JOS następująco:

\footnotetext{
Языковая картина мира - исторически сложившаяся в обыденном сознании данного языкового коллектива и отраженная в языке совокупность представлений о мире, определенный способ концептуализации действительности (Ènciklopediâ Krugosvet, źródło elektroniczne).
}

Według Bartmińskiego pojęcie JOS odwołuje się do hipotezy relatywizmu językowego Edwarda Sapira i Benjamina Lee Whorfa. Nawiązuje również do niemieckiej myśli lingwistycznej Wilhelma von Humboldta (który postrzegał język jako coś więcej niż narzędzie do porozumiewania się i wprowadził pojęcie Weltansicht - 'światoogląd') i Leona Weisgerbera (twórcy pojęcia Zwischenwelt - ‘językowy byt pośredni’) 3. W rzeczywistości sięga jednak korzeniami czasów

\footnotetext{
${ }^{3}$ Szeroko o koncepcji Zwischenwelt Weisgerbera zob. Mańczyk.
} 
reformacji ${ }^{4}$, a nawet starożytności, np. myśli Arystotelesa, poruszającego kwestię toposów, sądów ogólnie przyjętych, które ustanawiały wspólne punkty odniesienia w procesie wnioskowania i przekonywania, a więc sztuce retoryki (Bartmiński 11-12).

Pojęcie JOS pozwala docierać do mechanizmów, w jakich człowiek konceptualizuje świat. Koresponduje ono z rewolucją kognitywną, ukazując mentalność użytkowników języka. W metodologii JOS ważnym aspektem są kategorie. Badane pojęcie ujmowane jest w sposób kategorialny, tj. fasetowy, co według Bartmińskiego odpowiada ludzkiej potrzebie kategoryzacji zjawisk. Mechanizm kategoryzacji znajdziemy już w traktacie Kategorie Arystotelesa, w którym grecki filozof wyróżnia dziesięć kategorii ontologicznych: substancję, ilość, jakość, stosunek, miejsce, czas, położenie, działanie, doznawanie, posiadanie (Arystoteles 34). Inną propozycję przedstawił Immanuel Kant - jego zdaniem kategorie są pierwszymi i naczelnymi formami myślenia. Wymienia on cztery podstawowe takie formy: ilość, jakość, relacja i modalność. Te z kolei podlegają dalszemu podziałowi na trzy typy (Bartmiński 86). Jolanta Lubocha-Kruglik, odwołując się do prac lingwistów z petersburskiej szkoły gramatyki funkcjonalnej, wskazuje na istotną rolę kategorii perceptywności (Lubocha-Kruglik).

Próbę kategoryzacji zjawisk dźwiękowych podjęła Swietłana Stefanowskaja (Stefanovskaâ), która przedstawiła dźwiękowy obraz świata, wykorzystując ujęcie kategorialne. Zdaniem badaczki, świat dźwięków dzieli się na:

1. Ożywiony świat dźwięków, w ramach którego wyodrębnia ona podkategorie:

1.1. Człowiek (dźwięki wydawane przez człowieka, jako istotę biologiczną, jako istotę czującą i mówiącą, dźwięki człowieka pracującego, dźwięki człowieka twórcy),

1.2. Nie-człowiek (odgłosy świata zwierząt, odgłosy świata roślin);

2. Nieożywiony świat dźwięków, z podkategoriami:

2.1. Dźwięki przyrody nieożywionej,

2.2. Inne dźwięki otaczającego świata.

Podział ten wydaje się zasadny, choć pomija filozoficzny aspekt dźwięku, obecny w koncepcji pitagorejczyków, rozwiniętej przez Boecjusza w V wieku n.e., mówiącej o muzyce sfer (musica mundana) jako jednym z elementów trójdzielnej klasyfikacji (musica mundana, musica humana, musica instrumentalis).

Kwestia dźwięku zajmuje wielu badaczy języka. Polskie prace dotyczą przede wszystkim dźwięków mowy, badań semantycznych nad jednostkami nazywają-

${ }^{4}$ Martin Luter był zdania, że specyfika języków decyduje o pojmowaniu świata. Istotne wydaje się też sformułowane w dobie oświecenia twierdzenie Kartezjusza o tym, że „znaczenie to obecność przedmiotu w świadomości podmiotu" (Mańczyk, cyt. za: Niesporek-Szamburska 23). 
cymi dźwięki oraz nad percepcją zmysłową (zob. Bańko; Bartnicka-Dąbkowska; Grochowski; Grzesiak; Kładoczny; Kozarzewska; Żurowski 2012). Badania prowadzone w Rosji koncentrują się na kognitywnych aspektach zjawisk dźwiękowych (por. Evtugova; Livenec; Kuraškina).

\section{Językowy obraz dźwięku}

Zaprezentowana poniżej charakterystyka dźwięku nie rości sobie prawa do kompletności, jest jedynie wycinkiem językowego obrazu dźwięku. Ze względu na synestezyjny sposób przedstawiania zjawisk dźwiękowych charakterystyczny dla autorów recenzji muzycznych materiał leksykalny został podzielony według typu zmysłu, w ramach którego dane wrażenie dźwiękowe jest konceptualizowane. Na potrzeby analizy wyekscerpowano 145 wyrazów i zwrotów w języku rosyjskim oraz $145 \mathrm{w}$ języku polskim. Materiał badawczy pozwolił na wyodrębnienie kategorii, wśród których część ma pochodzenie arystotelesowskie. Pozostałe kategorie są charakterystyczne dla danego materiału i zostały utworzone na potrzeby poniższej analizy.

\section{Wzrokowe ujęcie wrażeń dźwiękowych}

\subsection{Konceptualizacje w języku rosyjskim (110 jednostek)}

Kategorie wyłaniające się z materiału zawierającego rosyjskojęzyczne konceptualizacje, w których bodźce dźwiękowe są ujmowane jako odnoszące się do zmysłu wzroku, to: JAKOŚĆ, KSZTAŁT, SUBSTANCJA, WIELKOŚĆ, SZTUKI PLASTYCZNE oraz MIEJSCE. Najliczniej reprezentowaną kategorią wśród synestezji typu dźwięk - wzrok w rosyjskojęzycznych recenzjach jest JAKOŚĆ. Wśród konceptualizacji odnoszących się do jakości dźwięku najliczniejszą grupę tworzą te, w których dźwięk ujmowany jest jako przejrzystość oraz światlo. Konceptualizacje dźwięku dotyczące przejrzystości cechują się częstym użyciem wyrazu прозрачный: тусклый звук; прозрачный звук; белесый звук; матовое звучание; туманное звучание; мутное звучание; прозрачное звучание; концентрация прозрачности в звучании; качество звучания - абсолютно ювелирное, прозрачное; распльвчатое звучание; насыщенное звучание; прозрачно звучать; звучать тускло; прозрачно звучащий; кристально звучащий. Dźwięk przyrównywany do światla odnotowano w następujących przykładach: блестящий звук; светлый звук; ясный звук; просветленный звук; яркий звук; просвещенный звук; свето-звук; проясненность звука; хрустально-ясньй звук; звучание может светиться тихим светом; ясное звучание; звучать светло; звучать блестяще; звучать ярко; звучать ясно; 
звучать с блеском. Kolejnym pod względem typowości jakościowym aspektem wrażeń dźwiękowych odbieranych jako wrażenia wzrokowe jest piękno: красота звука; прекрасный звук; разнообразно красивый звук; красивые звуки; редкой красоть звучание; красота звучания; перфекиионистская красота оркестрового звучания. Do grupy wyrażeń opisujących piękno zewnętrzne wrażeń dźwiękowych zaliczono także: стройное звучание; иикарное (оркестровое) звучание. Najmniej liczną grupę konceptualizacji zawiera podkategoria czystość, którą w kontekście dźwięku można rozumieć jako „wolny od fałszu” bądź „dźwięczny, wyraźny”: звук кристальной чистоты; звук чистый; промытый звук; звук чист; чистый до истонченности; чистейшее звучание скрипки; чистые звучания; кристальная чистота звучания.

Drugą kategorię, KSZTALT, wypełniają konceptualizacje: округльій звук; плоский звук, тычковый звук; ровный по всей длине звук; ровный звук; собранный в тугой узел звук саксонцев; ершистый звук; полное звучание; наполненное звучание; глубокое звучание; глубина звучания; намеренно неотесанные звучания; гибкость звучания; звуковая форма; звуковой котел; звуковые линии; звук, окутывающий со всех сторон. Wśród nich można wyróżnić podkategorię budowla, w której wrażenia dźwiękowe są przyrównywane do elementów architektury, budynków: изомренно-простоватые звуковые комплексы; иентр звуковой конструкции; звуковой фундамент; урбанистические звучания.

Kolejną kategorią jest SUBSTANCJA, którą tworzą następujące określenia dźwięku: кристальный звук; пластичный оркестровый звук; хрустальный звук; дубоватый звук; кристаллический звук; звук масленый; прозрачная плавность звучания; жирное звучание; звуковая волна; звуковой поток; звуковые краски. Zwracają uwagę wyrażenia przyrównujące dźwięki do tkanek ciała: бесплотный звук; плотный звук; полнокровное звучание; плотное звучание; мясистый звук.

Dźwięki mogą także cechować się WIELKOŚCIĄ. Należy przy tym podkreślić, że takie określenia, jak грандиозный, могучий, масштабный odnoszą się zazwyczaj do brzmienia orkiestry, w celu nazwania dźwięku pojedynczego instrumentu stosowane są natomiast określenia большой, крупный, небольшой: большой звук; грандиозный по силе звук; крупный звук; небольшой звук; объемный звук; массивные звучания; огромные площади могучего туттийного звучания; звучание большое; насыщенной мощности звучание; звуковой объем; прозвучать масштабно; по-шубертовски масштабно звучать.

Na ciekawą, zróżnicowaną kategorię SZTUKI PLASTYCZNE, podkreślającą związek dźwięku z malarstwem i innymi sztukami pięknymi, składają się: похожее на темперную живопись звучание; гуамевые мазки оркестрового 
звучания; живописное звучание; дивной красоты звуковые картины; звуковая палитра; звуковые образы; звуковые пейзажи; пестрая и опрятная звуковая картина; звуковые зарисовки; звуковая иллюстрация; великолепные звуковые картинь.

Ostatnią kategorią odnoszącą się do wrażeń dźwiękowych ujmowanych jako wrażenia wzrokowe jest MIEJSCE, do której przypisano pojedynczą konceptualizację: звуковое пространство.

\subsection{Konceptualizacje w języku polskim (113 jednostek)}

Materiał polskojęzyczny pozwolił wyodrębnić kategorie: JAKOŚĆ, SUBSTANCJA, KSZTALT, SZTUKI PLASTYCZNE, WIELKOŚĆ oraz SILA.

W ramach kategorii JAKOŚĆ zwracają uwagę wyrażenia nawiązujące do cech zewnętrznych, które utworzyły podkategorię piękno: piękny dźwięk; przepiękne połaczenie brzmień; piękna barwa dźwięku; piękno brzmienia; szczególnie pięknie zabrzmieć; piękne nietemperowane wspótbrzmienia; uroda dźwiękowa; brzmieniowa uroda; ładnie brzmiace; uroda brzmienia oraz podkategorię brzydota: brutalne i „brzydkie” dźwięki; brzydki, toporny dźwięk; brzmienia blachy moga zafrapować swa szorstka uroda; nieładny dźwięk.

Kolejną podkategorią jakościową jest barwa, wzmiankowana w następujących wyrażeniach: nasycenie brzmienia; dźwięk nasycony; barwy dźwięku; barwy brzmienia; kolorystyka brzmienia; wielobarwny klimat dźwiękowy; ,,szary”, dźwięk; brzmieć jaskrawo; bezbarwny dźwięk. Do tej grupy włączono także określenia dotyczące przejrzystości brzmień: przezroczysty dźwięk; przejrzyste erardowskie brzmienie, które w przeciwieństwie do licznych analogicznych poświadczeń w rosyjskojęzycznym materiale nie utworzyły osobnej podkategorii. Dość szeroko reprezentowana jest natomiast podkategoria światło: rozjaśniony dźwięk stradivariusa; mieniace się dźwięki; olśnić kaskadami dwudźwięków; migotliwe dźwięki; dźwięk się rozprasza; jasny, szklisty dźwięk; jasny i błyszczacy dźwięk; wygasający dźwięk; wiąka dźwięków; szkliste dźwięki. Jak już wspomniano w odniesieniu do rosyjskojęzycznych przykładów, wrażenia dźwiękowe mogą być również konceptualizowane poprzez odniesienie ich do czystości: dźwięk czysty; czyste brzmienia; czysto brzmiacy; krystalicznie czysty dźwięk.

Kolejną kategorię, SUBSTANCJA, wypełniają wyrażenia: metaliczne brzmienie; brzmienie ze stosowna domieszka ,,metalu”; brzmieć krystalicznie; krystaliczne brzmienie; perlisty dźwięk; dźwiękowe klejnoty - kragłe perełki i precyzyjnie oszlifowane kamienie szlachetne; dźwiękowe ucieleśnienie. W jej ramach można wydzielić dwie podkategorie: ciecz, która ilustruje przede wszystkim „płynny” charakter wrażeń dźwiękowych: płynność materii dźwiękowej; „płynne" elementy dźwiękowe przechodza w stan ",gazowy”; mikstury dźwiękowe, płynnie zmieniajace skład, kształt i , konsystencje”,; źródło dźwięku; ,pływajace” 
dźwięki; rozrzedzone brzmienia; fala dźwięków; chmura dźwiękowa, oraz tkanina: atrakcyjna szata brzmieniowa; koronka wspótbrzmień; materia dźwiękowa; materiat dźwiękowy.

Wielokrotnie konceptualizowany jest dźwięk jako mający formę KSZTALT: brzmieniowy ksztatt; podstawa dźwiękowa; płaszczyzny brzmieniowe; kaskady dźwięku; rozwarstwiające się brzmienie; plamy brzmieniowe; wyrównane brzmienie; figury dźwiękowe; symetria brzmieniowa; dźwięk oszlifowany jak perta; nabrzmiewające dźwięki; , ukośne” brzmienia; plaskie brzmienie; girlandy dźwięków; brzmienia, które „otulaja” muzykę. Warto zwrócić uwagę na konceptualizacje ilustrujące dźwięk jako okrągly: kragły dźwięk; dźwięk petny, okragły; zaokraglone dźwięki; brzmienie orkiestry kragłe, oraz kanciasty: ostro brzmiace; brzmieć kanciasto; ostrzejszy w brzmieniu; zaostrzone erardowskie brzmienie. Analogicznie do rosyjskojęzycznego materiału polskojęzyczni recenzenci także dokonują porównania dźwięku do konstrukcji, budowli: umocowany na kilku tych samych, pojawiających się w różnych oktawach dźwiękach; proporcje dźwiękowe; zbudowany wyłacznie z dźwięków; konstrukcje dźwiękowe; wsparty nasyconym, potężnym dźwiękiem.

Przedostatnią kategorię, WIELKOŚĆ, ilustrują poniższe wyrażenia: krótsze wybrzmiewania; dźwięki krótkie i dlugie; dźwięk niski; wysokie dźwięki; potężna, symfoniczna masa brzmienia; potężne brzmienia blachy; spektrum dźwiękowe; potęga brzmienia; masa i głębia brzmienia; spektralne wspótbrzmienia.

Najmniej liczna okazała się kategoria SILA: niespotykana siła dźwięku; brzmienie mocne, przepojone sita; mocne dźwięki.

Podobnie jak w rosyjskich konceptualizacjach, sporą grupę stanowią określenia nawiązujące do SZTUK PLASTYCZNYCH: dźwiękowe tło; brzmieniowy kształt kompozycji; rozrzedzony obraz dźwiękowy; malarstwo dźwiękowe; pastelowe brzmienie; wyostrzony obraz dźwiękowy; żywy i intrygujący dźwiękowy obraz baroku; fresk brzmieniowy; pejzaż brzmień; świat malowany dźwiękiem; malowania ekstrawaganckich dźwiękowych obrazów; paleta brzmień. Do tej grupy zaliczono również widokówki dźwiękowe oraz pocztówkę dźwiękowa.

2. Dotykowe ujęcie wrażeń dźwiękowych

2.1. Konceptualizacje w języku rosyjskim (27 jednostek)

W konceptualizacjach wrażeń dźwiękowych odbieranych zmysłem dotyku można wyodrębnić dwie kategorie: JAKOŚĆ i SUBSTANCJA.

Jakościowe ujęcie wrażeń dźwiękowych ilustrują podkategorie faktura: звуковая фактура; фактурное звучание; miękkość: мягкий оркестровый звук; мягко переливающийся звук; мягкое звучание; мягкость в звучании; мягко утопать в повторяющихся звучностях; temperatura: теплый звук; 
холодный звук; теплое звучание; звучать тепло; звучать с теплотой; waga: звук легкий; весомое звучание; зазвучать невесомо.

W ramach kategorii SUBSTANCJA znalazły się następujące wyrażenia i zwroty: бархатный звук; вылуплять и вылеплять каждый звук; звуки - ловкие пригоршни фортепианного бисера. Nieliczną podkategorię gęstość zestawiły: густенько звучать; густые звучания. Nieco więcej poświadczeń utworzyło podkategorię suchość: звучать сухо; звучать суховато; звучать шершаво; сухое звучание; суховат звук. Do wrażeń dźwiękowych konceptualizowanych jako dotykowe włączono również: физиологически осязаемый звук; осязаемые звуки.

\subsection{Konceptualizacje w języku polskim (22 jednostki)}

Podobnie jak w języku rosyjskim w polskich przykładach konceptualizacje wrażeń dźwiękowych odbieranych jako wrażenia dotykowe zestawiły dwie kategorie: JAKOŚĆ oraz SUBSTANCJA.

Jakościowe ujęcie wrażeń dźwiękowych dają następujące przykłady: pulsujące wspótbrzmienie; brzmienie kruche; uwypuklenie dźwięków. Analogiczne do rosyjskojęzycznych podkategorie temperatura i waga reprezentują jednostkowe przykłady: brzmienie chtodne oraz lekko brzmiacy. Nieco liczniejszą reprezentację ma podkategoria, w której podkreślona jest szorstkość dźwięku: brzmienie szorstkie; szorstki dźwięk; zabrzmieć szorstko.

Kategorię SUBSTANCJA tworzą natomiast: sypka masa dźwiękowa; dźwięki wyrzeźbione, i to $w$ twardym tworzywie, niz wymodelowane; aksamitny dźwięk; masa dźwiękowa zarazem gęsta i ptynna; głębsze i plastyczne brzmienie; aksamitnie brzmiaca kantylena. W ramach tej kategorii wyróżniono podkategorię gęstość: gęstość barwy dźwięku; gęsto brzmiące faktury; dźwięk, jego barwa, gęstościa, ciężarem; koloryt gęstych wspótbrzmień oraz podkategorię miękkość: miękki dźwięk; miękko brzmieć; miękkie, spoiste brzmienie.

\section{Smakowe ujęcie wrażeń dźwiękowych}

\subsection{Konceptualizacje w języku rosyjskim ( 8 jednostek)}

Jest to nieliczna grupa wyrażeń i zwrotów które utworzyły kategorię JAKOŚĆ: пряные звуки; звуки считаются одними из самых вкусных и полезных на нашем рекламном рынке; звук сочен; сытый звук; неаппетитная наслух звуковая масса; прозвучать с большим смаком. Jedynymi przykładami nawiązującymi bezpośrednio do określonego smaku są: сладчайший у скрипок oraz звучать не менее сладостно.

\subsection{Konceptualizacje w języku polskim (10 jednostek)}

Podobnie jak w przykładach w języku rosyjskim synestezje związane ze zmysłem smaku są najmniej liczną grupą składającą się na kategorię JAKOŚĆ: po- 
smak brzmienia orkiestrowego; smakowanie dźwięku; pieprznie brzmieć; brzmienie dodaje interpretacjom smaku; brzmienia orkiestrowe sa bardzo wysmakowane. W tej grupie można wyróżnić podkategorię soczystość, zilustrowaną poniższymi przykładami: soczyste brzmienie; zabrzmieć soczyście; soczyście brzmiaca orkiestra. Podobnie jak w rosyjskojęzycznym materiale dwa przykłady odnoszą się bezpośrednio do konkretnych smaków (dźwięk słodki; brzmienie petne goryczy).

\section{Podsumowanie}

Z przeprowadzonej próby rekonstrukcji językowego obrazu dźwięku wynika, że najwięcej poświadczeń (w języku rosyjskim 110 jednostek - 75,5\%, w języku polskim 113 jednostek - 78\%) dotyczy wzrokowego ujęcia wrażeń dźwiękowych, co sugeruje, że wrażenia słuchowe najczęściej konceptualizowane są za pomocą zmysłu wzroku. Wniosek ten odpowiada powszechnie znanemu sądowi, iż najwięcej bodźców odbieramy zmysłem wzroku (mimo że ewolucyjnie ten zmysł jest najmłodszy ${ }^{5}$. Wrażenia dźwiękowe ujmowane jako bodźce dotykowe odnotowano w 27 (19\%) przykładach w języku rosyjskim oraz 22 (15\%) przykładach w języku polskim. Najmniej liczne okazały się konceptualizacje dźwięk - smak, mające swoje odzwierciedlenie w 8 (5,5\%) wyrażeniach w języku rosyjskim oraz $10(7 \%)$ w języku polskim. Zarówno w polsko-, jak i rosyjskojęzycznych recenzjach nie odnotowano konceptualizacji odwołujących się do zmysłu powonienia. Biorąc pod uwagę typy kategorii, należy stwierdzić, że w obu językach dźwięk najczęściej jest opisywany w arystotelesowskich aspektach: JAKOŚĆ (72 wyrażenia w języku rosyjskim i 57 w języku polskim), SUBSTANCJA (28 wyrażeń w języku rosyjskim i 33 wyrażenia w języku polskim) oraz KSZTALT (17 wyrażeń w języku rosyjskim i $15 \mathrm{w}$ języku polskim). Wrażenia dźwiękowe konceptualizowane są najczęściej jako mające cechy: przejrzystość, światło, piękno (w języku rosyjskim), barwa, światlo, piękno (w języku polskim). Są to więc określenia nacechowane dodatnio, przyrównujące dźwięk do kryształu bądź innej substancji mającej ww. cechy. Interesujące jest użycie licznych metafor nawiązujących do sztuk plastycznych zarówno w języku polskim (14), jak i rosyjskim (11). Takie ujęcie wrażeń dźwiękowych odzwierciedla związki między sztukami, co tym bardziej zwraca uwagę na zjawisko synestezji (do correspondance des arts dążyło wielu artystów, jak choćby Eugène Delacroix czy Aleksandr Skriabin).

${ }^{5}$ Do takich wniosków doszedł S.A. Day po omówieniu kolejności metaforycznego transferu z jednej sfery sensorycznej do drugiej. Stephen Ullmann natomiast podkreślał rolę zmysłu smaku i powonienia w tworzeniu metafor (Day 1995). 
Analiza porównawcza ukazała wiele podobieństw między konceptualizacjami w języku polskim i rosyjskim. Analogie występują zarówno na poziomie typu synestezji (w obu językach zdecydowanie najwięcej konceptualizacji wrażeń dźwiękowych dotyczy relacji dźwięk - wzrok, również w obu częściach materiału nie odnaleziono synestezji odnoszącej się do zmysłu zapachu), jak i w obrębie kategorii (w obu językach konceptualizacje utworzyły te same kategorie, poza wyjątkami: kategorią MIEJSCE wyłącznie w języku rosyjskim oraz kategorią SILA wyłącznie w języku polskim), znacznej części podkategorii, jak i samych wyrażeń (por. brzmienia, które „otulaja” mиzykę oraz звук, окутьввающий со всех сторон; звуковые пейзажи oraz рејzaż brzmień; krystaliczne brzmienie oraz кристаллический звук). Przede wszystkim jednak próba rekonstrukcji językowego obrazu dźwięku ukazała różnorodność środków językowych polsko- i rosyjskojęzycznych krytyków muzycznych, bogactwo wyrażeń określających wrażenia dźwiękowe oraz ów amalgamat zmysłów, jakim jest zjawisko synestezji.

\section{Bibliografia}

Adamowski, Jan et al., red. Stownik ludowych stereotypów językowych: zeszyt próbny. Wrocław, Wydawnictwo Uniwersytetu Wrocławskiego, 1980.

Apresjan, Jurij. „Naiwny obraz świata a leksykografia”. Przeł. Joanna Berej, Anna Pajdzińska. Etnolingwistyka, 6, 1994, s. 5-12.

Arystoteles. Dzieła wszystkie. T. 1. Przeł. Kazimierz Leśniak. Warszawa, PWN, 1999.

Bańko, Mirosław. Słownik onomatopei, czyli wyrazów dźwięko- i ruchonaśladowczych. Warszawa, Wydawnictwo Naukowe PWN, 2009.

Bartmiński, Jerzy. Językowe podstawy obrazu świata. Lublin, Wydawnictwo Uniwersytetu Marii Curie-Skłodowskiej, 2006.

Bartnicka-Dąbkowska, Barbara. Stownictwo pism Stefana Żeromskiego. T. 4: Świat dźwięków. Kraków, Towarzystwo Autorów i Wydawców Prac Naukowych „Universitas”, 2002.

Day, Sean Andrew. Synaesthetic metaphors in English. West Lafayette, Indiana, Purdue University, 1995.

Day, Sean Andrew. „Synaesthesia and Synaesthetic Metaphors”. Psyche, 2 (32), 1996. Web. 21.02.2020. https://www.researchgate.net/profile/Sean_Day/publication/215974628_ Synaesthesia_and_synaesthetic_metaphors/links/0975879ea17c9c578bd7f822/Synaesthesiaand-synaesthetic-metaphors.pdf.

Doroszewski, Witold, red. Stownik języka polskiego. T. 2. Warszawa, Wydawnictwo Naukowe PWN, 1996.

Efremova, Tat'âna F. Novyj slovar' russkogo âzyka. Tolkovo-slovoobrazovatel'nyj. Moskva, Russkij âzyk, 2000. Web. 09.04.2021. https://dic.academic.ru/dic.nsf/efremova/168198/\%D0\%97\%D $0 \% \mathrm{~B} 2 \% \mathrm{D} 1 \% 83 \% \mathrm{D} 0 \% \mathrm{BA}$.

Ènciklopediâ Krugosvet. Web. 24.08.2019. https://www.krugosvet.ru/enc/gumanitarnye_nauki/ lingvistika/YAZIKOVAYA_KARTINA_MIRA.html.

Evtugova, Natal'â N. Semantiko-kognitivnoe issledovanie nominativnogo polâ zvučaniâ kak fragmenta nemeckoj âzykovoj kartiny mira. Omsk, 2010. Web.24.08.2019. http://cheloveknauka. 
com/semantiko-kognitivnoe-issledovanie-zvuchaniya-kak-fragmenta-nemetskoy-yazykovoykartiny-mira.

Grochowski, Maciej. „O założeniach eksplikacji znaczeń czasowników percepcji słuchowej”. Studia Linguistica Polono-Jugoslavica, 7, 1993, s. 57-64.

Grzesiak, Romuald. Semantyka i składnia czasowników percepcji zmysłowej. Wrocław, Zakład Narodowy im. Ossolińskich, 1983.

Hanslick, Eduard. O pięknie muzycznym. Przyczynek do rewizji estetyki sztuki dźwięków. Przeł. Joanna Giel. Wrocław, Wydawnictwo Uniwersytetu Wrocławskiego, 2017.

Kaczyński, Tadeusz. Messiaen. Kraków, Polskie Wydawnictwo Muzyczne, 1984.

Kandyński, Wasyl. Punkt i linia a płaszczyzna. Warszawa, Państwowy Instytut Wydawniczy, 1986.

Kładoczny, Piotr. Semantyka nazw dźwięków w języku polskim. T. 1-2. Łask, Oficyna Wydawnicza Leksem, 2012.

Kozarzewska, Emilia. „Grupy semantyczne nazw dźwięków w języku polskim”. Poradnik Językowy, 5, 1976, s. 239-247.

Kuraškina, Nataliâ A. Zvukooboznačeniâ kak reprezentaciâ zvukosfery v âzyke: na materiale anglijskih, francuzskih i russkih antropo- $i$ ornitofonov. Ufa, 2007. Web. 24.08.2019. https:// www.dissercat.com/content/zvukooboznacheniya-kak-reprezentatsiya-zvukosfery-v-yazykena-materiale-angliiskikh-frantsuz.

Livenec, Irina S. Koncept VOZDUH v lingvokul'turologičeskom aspekte: na materiale tekstov K. Paustovskogo i M. Šolohova. Belgorod, 2007. Web. 24.08.2019. https://www.dissercat. $\mathrm{com} /$ content/kontsept-vozdukh-v-lingvokulturologicheskom-aspekte-na-materiale-tekstov-kpaustovskogo-i-m-.

Lubocha-Kruglik, Jolanta. Semantyczna kategoria perceptywności i jej wykładniki w języku polskim i rosyjskim. Katowice, Wydawnictwo Uniwersytetu Śląskiego, 2010.

Mańczyk, Augustyn. Wspólnota językowa i jej obraz świata. Zielona Góra, Wydawnictwo Wyższej Szkoły Pedagogicznej, 1982.

Niesporek-Szamburska, Bernadeta. Językowy obraz pór roku i tradycji kulturowych w twórczości dzieci. Katowice, Wydawnictwo Uniwersytetu Śląskiego, 2004.

Ožegov, Sergej I., red. Slovar' russkogo âzyka. Moskva, Russkij âzyk, 1990.

Ramachandran, Vilayanur S., Edward M. Hubbard. „Synaesthesia - A window into perception, thought and language". Journal of Consciousness Studies, 8 (12), 2001, s. 3-34.

Rogowska, Aleksandra. „U źródeł synestezji: podstawy fizjologiczne i funkcjonalne”. Przeglad Psychologiczny, 45 (4), 2002, s. 465-473.

Serebrennikov, Boris A., red. Rol' čelovečeskogo faktora v âzyke. Âzyk i kartina mira. Moskva, Nauka, 1988.

Sławiński, Janusz, red. Słownik terminów literackich. Wrocław, Zakład Narodowy im. Ossolińskich, 2008.

Stefanovskaâ, Svetlana V. „Zvukovaâ kartina mira”. Vestnik Irkutskogo gosudarstvennogo lingvističeskogo universiteta, 4, 2009, s. 117-121. Web. 09.10.2019. http://cyberleninka.ru/ article/n/zvukovaya-kartina-mira.

Śledziński, Stefan, red. Mała encyklopedia muzyki. Warszawa, Państwowe Wydawnictwo Naukowe, 1960.

Urbańczyk, Stanisław, red. Encyklopedia wiedzy o języku polskim. Wrocław, Zakład Narodowy im. Ossolińskich, 1978.

Żurowski, Sebastian. „Wokół problemu definiowania pojęcia dźwięk”. Linguistica Copernicana, 1 (1), 2009, s. 143-155.

Żurowski, Sebastian. Wyrażenia percepcji stuchowej w języku polskim. Analiza semantyczna. Toruń, Wydawnictwo Naukowe Uniwersytetu Mikołaja Kopernika, 2012. 